\title{
Recovery of tetrachloroaurate through ion exchange with Dowex 11 resin
}

\author{
F.J. Alguacil $\left.{ }^{*}\right)$
}

\begin{abstract}
The recovery of the tetrachloroaurate complex by the anionic ion exchange resin Dowex 11 has been studied. The kinetics of gold adsorption were dependent of both gold and resin concentrations and temperature. The adsorption isotherm can be described by the expression $Q=k C^{n}$. The loaded resin could be eluted by an acidic thiourea solution at $20^{\circ} \mathrm{C}$. After several adsorption-elution cycles there is not any apparent loss in the adsorption properties of the resin.
\end{abstract}

Keywords: Gold. Ion exchange. Dowex 11.

\section{Recuperación de $\mathrm{AuCl}_{4}^{-}$mediante intercambio iónico con la resina Dowex 11}

\begin{abstract}
Resumen Se estudia la recuperación del ion tetracloroaurato mediante la resina aniónica Dowex 11. La extracción de oro depende tanto de las concentraciones del metal y la resina como de la temperatura. La isoterma de adsorción responde a la ecuación $Q=k C^{n}$. La resina cargada con oro puede ser eluida con una disolución ácida de tiourea a $20^{\circ} \mathrm{C}$. Después de varios ciclos de adsorción-desorción no hay pérdida de carga por parte de la resina.
\end{abstract}

Palabras clave: Oro. Cambio iónico. Dowex 11.

\section{INTRODUCTION}

The majority of gold extraction flowsheets use hydrometallurgical techniques; the most important of which are leaching, solution purification and/or concentration and recovery of gold. Since gold is dissolved the purification and/or concentration of the pregnant solution is accomplished by one (or a combination) of these methods: carbon adsorption, ion exchange, solvent extraction, zinc cementation and electrowinning (1).

The use of ion exchange for the concentration and purification of gold has been investigated from years, although it seems that this technology had only been favoured in the ex-USSR against the use of carbon adsorption in the Western countries. However, the number of investigations on the potential

(*) Centro Nacional de Investigaciones Metalúrgicas, CENIM (CSIC), Avda. de Gregorio del Amo 8. 28040-Madrid (España). use of ion exchange resins in gold processing need to be considered (2-5).

The present work investigates the possibilities of the Dowex 11 resin on the adsorption of the tetrachloroaurate ion. Results on the resin regeneration and recycling are also present.

\section{EXPERIMENTAL}

The ion exchange resin Dowex 11 (Dow Chemical) used to adsorb gold from $\mathrm{HCl}$ media is a strongly basic anion exchanger containing an active group of trimethyl benzyl ammonium, it was used without any specific pretreatment. The adsorption experiments were carried out in funnels mechanically shaken at $500 \mathrm{rpm}$. The elution experiments were conducted in a $50 \mathrm{ml}$ burette. The loaded resin was packed with glass wool at the bottom of the resin bed and the eluant was passed through the bottom of the column with a pump at a given flow rate. All chemicals were of AR grade. Gold was analized by AAS. 


\section{RESULTS AND DISCUSSION}

\subsection{Gold adsorption}

\subsubsection{Influence of initial gold concentration}

The study of this variable on gold adsorption was carried out using $2.5 \mathrm{~g}$ resin and $500 \mathrm{ml}$ of aqueous solutions containing 5 to $80 \mathrm{mg} / \mathrm{L}$ gold $(\mathrm{pH} 1.7)$ at $20{ }^{\circ} \mathrm{C}$. Figure 1 shows that the adsorption rate was fast at the initial stage, more than 50 $\%$ of gold was adsorbed in less than 10 min with the resin load remaining constant after $30 \mathrm{~min}$ of contact with the aqueous solution.

\subsubsection{Influence of resin concentration}

Various concentrations of the resin ( 1 to $5 \mathrm{~g}$ ) were used to contact a $500 \mathrm{ml}$ solution of $20 \mathrm{mg} / \mathrm{L}$ gold at $20^{\circ} \mathrm{C}$. Figure 2 shows that the resin of 5 and $10 \mathrm{~g}$ adsorb more than $90 \%$ of metal from the solution in about 30 min with a resin load of 2 and 3.7 $\mathrm{g} / \mathrm{kg}$ gold respectively. The gold adsorption from the lower concentration of the resin is much slower. It seems that a resin concentration of near $5 \mathrm{~g} / 500$ $\mathrm{mL}$ is necessary to have good adsorption kinetic.

\subsubsection{Influence of temperature}

The influence of the temperature on the kinetics of resin load was studied at temperatures ranging

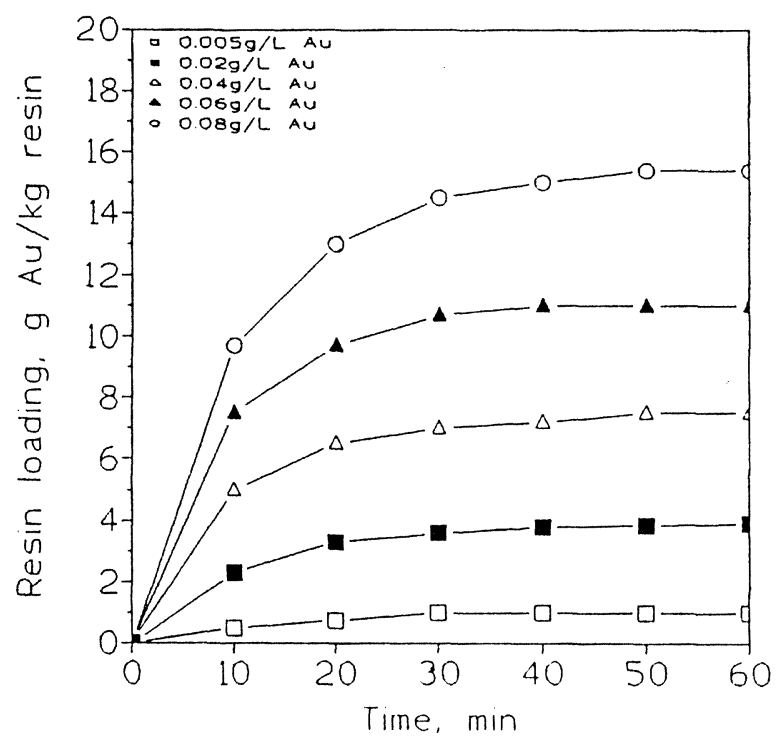

FIG. 1.- Influence of initial gold concentration on Dowex 11 loading.

FIG. 1.- Influencia de la concentración inicial de oro sobre la carga de la resina Dowex 11.

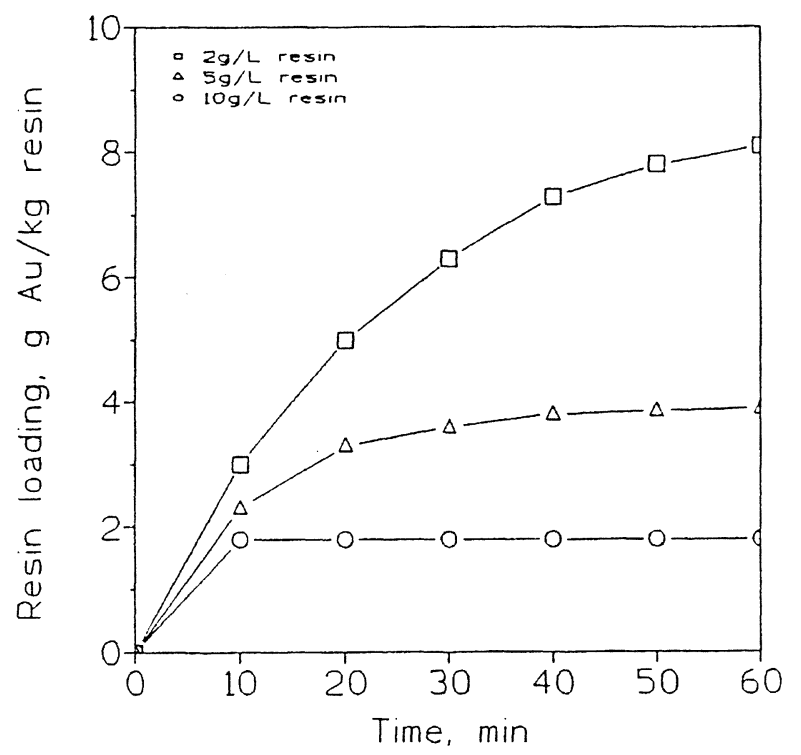

FIG. 2.- Influence of Dowex 11 concentration on loading kinetics.

FIG. 2.- Influencia de la concentración de Dowex 11 sobre la cinética de carga.

from 20 to $80{ }^{\circ} \mathrm{C}$ using $5 \mathrm{~g}$ resin in contact with $500 \mathrm{ml}$ of a solution containing $20 \mathrm{mg} / \mathrm{L}$ gold. Figure 3 shows that the increase in temperature accelerated the adsorption kinetics up to $45^{\circ} \mathrm{C}$. At higher temperatures gold adsorption decreases possibly due to a desorption process. Thus the operating

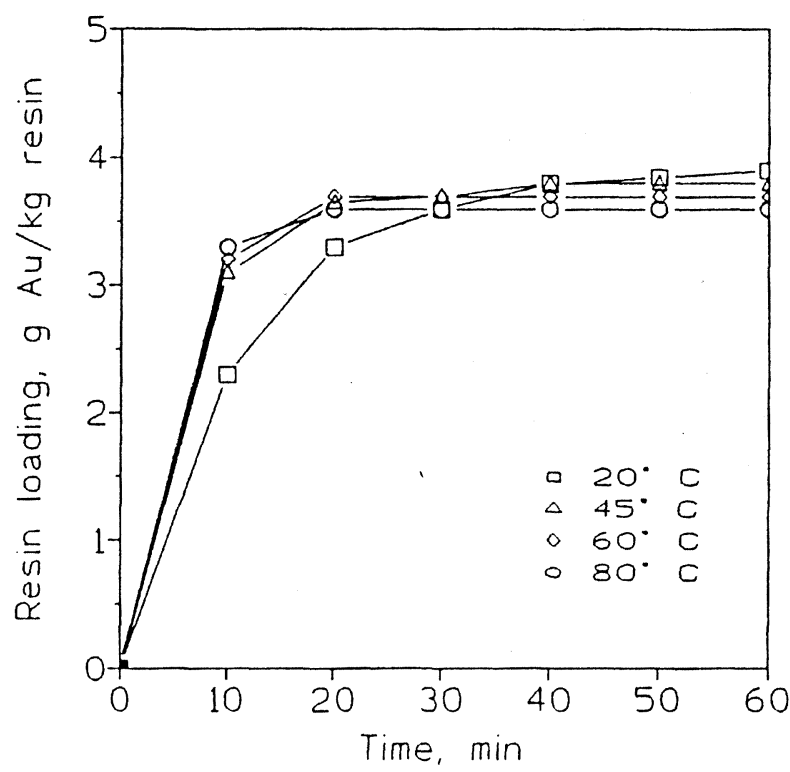

FIG. 3.- Influence of temperature on loading kinetics.

FIG. 3.- Influencia de la temperatura sobre la cinética de carga. 
temperature for gold adsorption should not be higher than $40^{\circ} \mathrm{C}$.

\subsubsection{Adsorption isotherm}

The adsorption isotherm of Dowex 11 was determined at $20{ }^{\circ} \mathrm{C}$ in a $200 \mathrm{~mL}$ aqueous solution containing an initial gold concentration of 100 $\mathrm{mg} / \mathrm{L}$ at $\mathrm{pH} 1.75$ for $2 \mathrm{~h}$. Concentrations of 0.2 to 1 $\mathrm{g}$ of resin (wet) were used. Figure 4 shows that there is an increase in the resin load with the increase in gold equilibrium concentration. Gold load can be described by the expression:

$$
Q=k C^{n}
$$

where $Q$ is the resin load in $\mathrm{g} / \mathrm{kg}$ gold, $C$ is the equilibrium concentration of gold in $\mathrm{mg} / \mathrm{L}$ while $n$ and $k$ are constants. The experimental results of $n$ and $k$ values for the tetrachloroaurate adsorbed on Dowex 11 were 0.86 and 52.5 respectively. The resin load would be near $50 \mathrm{~g} / \mathrm{kg}$ at an equilibrium concentration of $1 \mathrm{mg} / \mathrm{L}$ gold.

\subsubsection{Gold adsorption mechanism}

The active group of Dowex 11 is responsible for exchange with the $\mathrm{AuCl}_{4}^{-}$from the aqueous solution as shown below:

$$
\begin{gathered}
\mathrm{J}_{-}^{+} \mathrm{RN}\left(\mathrm{CH}_{3}\right)_{3} \mathrm{Cl}^{-}+\mathrm{AuCl}_{4}^{-} \\
\rightarrow]_{-}^{+} \mathrm{RN}\left(\mathrm{CH}_{3}\right)_{3} \mathrm{AuCl}_{4}^{-}+\mathrm{Cl}_{\mathrm{aq}}^{-}
\end{gathered}
$$

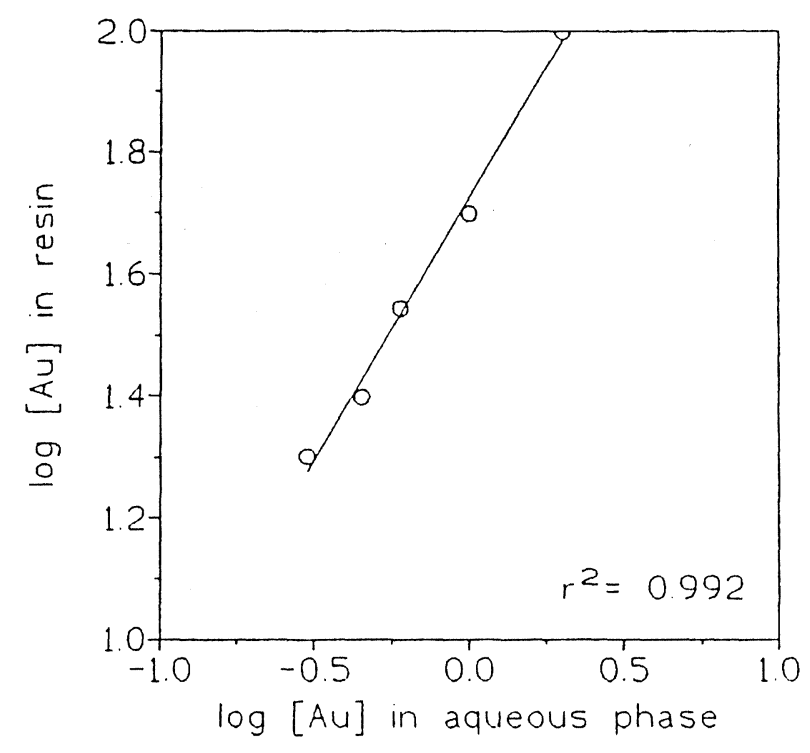

FIG. 4.- Gold adsorption isotherm.

FIG. 4.- Isoterma de adsorción de oro. where $R$ represents a carbon chain (the benzyl group linked to the inert resin matrix). The electron configuration of gold (III) is $\mathrm{Xe}_{4} \mathrm{f}^{14} 5 \mathrm{~d}^{8}$ and is expected to have fast kinetics both in ionic association and in coordination mechanism (6). The results obtained in this work have confirmed the fast kinetics of tetrachloroaurate adsorption.

\subsection{Gold elution}

\subsubsection{Influence of the eluant concentration}

Strongly basic ion exchangers have good loading capacities but are difficult to be eluted. One possibility is the use of acidic thiourea solutions. A resin load of $4 \mathrm{~g} / \mathrm{kg}$ gold was used in the elution experiments, the aqueous solution containing thiourea and $3.5 \mathrm{~g} / \mathrm{L}$ hydrochloric acid was passed through the resin bed at a flow rate of $10.4 \mathrm{BV} / \mathrm{h}$ and $25^{\circ} \mathrm{C}$. Figure 5 shows that near $80 \%$ of gold was eluted by $34 \mathrm{BV}$ thiourea solution at a concentration of 10 $\mathrm{g} / \mathrm{L}$ thiourea. The increase in the thiourea concentration increases the percentage of gold elution.

\subsubsection{Influence of the eluant flow rate}

Various eluant flow rates were used to study its influence on gold desorption. Gold elution from the resin can be enhanced using lower flow rates but longer elution times (Fig. 6).

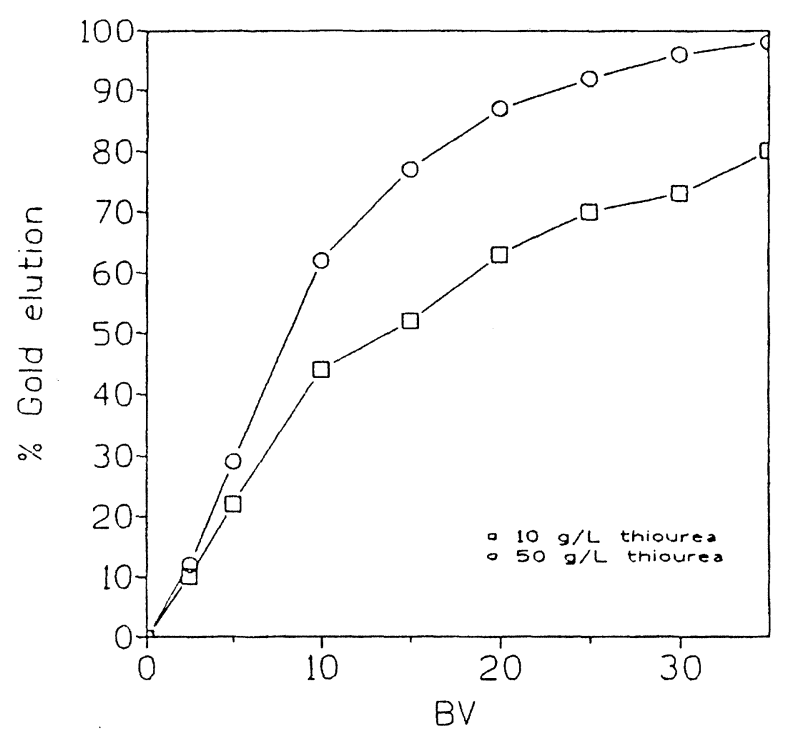

FIG. 5.- Effect of thiourea concentration on gold elution.

FIG. 5.- Efecto de la concentración de tiourea sobre la concentración de oro. 


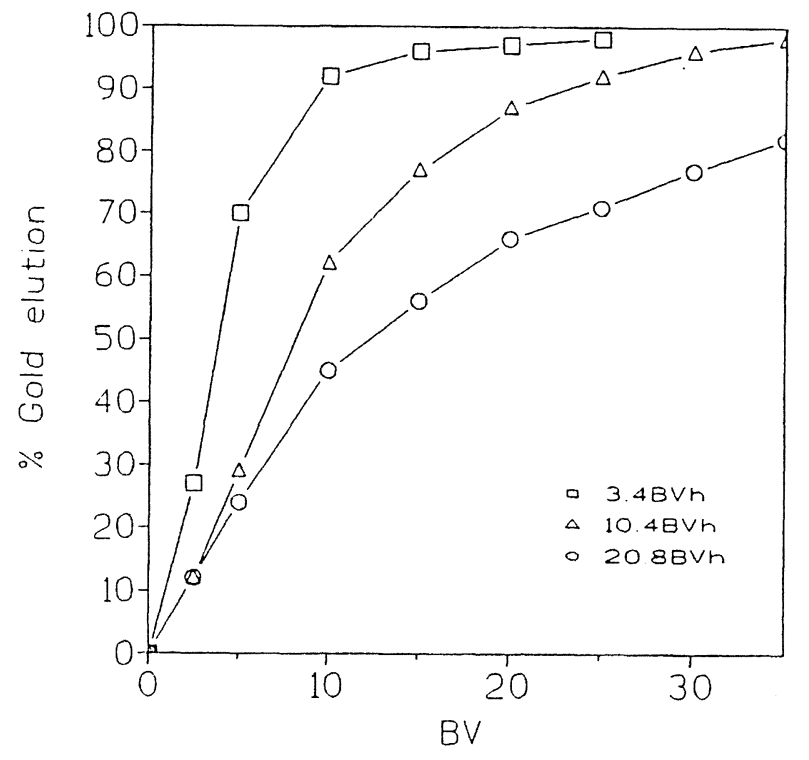

FIG. 6 - Effect of flow rate on gold elution.

FIG. 6.-Efecto del flujo sobre la elución de oro.

\subsubsection{Gold desorption mechanism}

At this stage, $\mathrm{Au}(\mathrm{III})$ is reduced to the (I) state, since $\mathrm{Au}(\mathrm{III})$ does not form any complex with thiourea, and then complexed with the ligand according with the apparent reaction:

$$
\begin{gathered}
]_{-}^{+} \mathrm{RN}\left(\mathrm{CH}_{3}\right)_{3} \mathrm{AuCl}_{4}^{-}+2 \mathrm{TU}_{\mathrm{aq}} \rightarrow \\
\rightarrow]_{-}^{+} \mathrm{RN}\left(\mathrm{CH}_{3}\right)_{3} \mathrm{Cl}^{-}+\mathrm{Au}(\mathrm{TU})_{2}^{+} \mathrm{Cl}_{\mathrm{aq}}^{-}+\mathrm{Cl}_{2}[3]
\end{gathered}
$$

where TU represented the thiourea molecule $\mathrm{CS}\left(\mathrm{NH}_{2}\right)_{2}$. As expected from this reaction as the thiourea concentration is increased the gold elution process is also enhanced.

\subsection{Resin regeneration}

The use of an operation like ion exchange in the recovery of metals needed of the regeneration of the resin for its use in various cycles. Before the resin is recycled for adsorption, the desorbed exchanger surface must be converted or regenerated to the proper ionic form to achieve optimum adsorption. Thus, after elution with thiourea, it is necessary to wash any entrained thiourea on the resin surface.

Regeneration can be accomplished using acidic solutions, e.g. $25 \mathrm{~g} / \mathrm{L} \mathrm{HCl}$. Regeneration of the resin was maintained during $2 \mathrm{~h}$ and afterwards the resin was washed with water in order to eliminate the acid excess from the resin. After this treatment the resin was again loaded with gold; results shown in figure 7 indicate that the resin maintains the

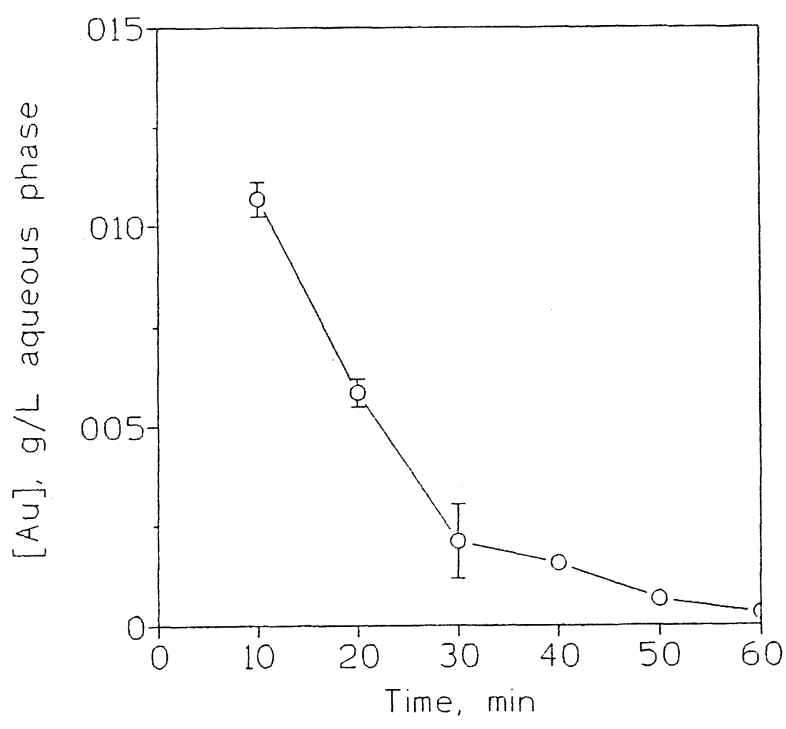

FIG. 7.- Variation of gold residual concentration in the aqueous phase $v s$ time for cycles of adsorptiondesorption-regeneration. Gold concentration values represented average data of five cycles.

FIG. 7.- Variación de la concentración residual de oro en la fase acuosa frente al tiempo para ciclos de adsorción-elución-regeneración. Los valores de concentración de oro representan los valores medios de cinco ciclos.

same adsorption activity after five cycles of adsorption-desorption.

\section{CONCLUSIONS}

Gold adsorption from $\mathrm{HCl}$ media on Dowex 11 resin is fast having the resin a loading capacity even of the same magnitude order than activated carbon. Under typical conditions of $5 \mathrm{~g}$ of resin per liter of solution more than $95 \%$ of gold could be recovered by the resin in less than $1 \mathrm{~h}$ at $20^{\circ} \mathrm{C}$. Adsorption kinetics increases as the temperature is increased up to $45^{\circ} \mathrm{C}$. The loaded resin could be eluted with an acidic solution of thiourea at $20^{\circ} \mathrm{C}$; elution is preferred at slow eluant flow rates. The resin can be regenerated with an slightly $\mathrm{HCl}$ aqueous solution and recycled apparently without losing its adsorption-desorption activity.

\section{REFERENCES}

(1) Yannopoulos, J.C. The Extractive Metallurgy of Gold, Van Nostrand Reinhold, Nueva York, 1991: 185-239.

(2) Hiskey, J.B. and JiAnG, X.H. Advances in Gold and Silver Processing, M.C. Fuerstenau and J.L. Hendrix (Eds.), SME-AIME, Warrendale (PA, USA), 1990: 277-284. 
(3) WAn, R.Y. and BALL, B. Proc. 119th TMS Annual Meeting, Anaheim, 1990.

(4) Marsden, J. and House, I. The Chemistry of Gold Extraction, Ellis Horwood, Chichester, 1992: 351-367.

(5) Wan, R.Y., LeVIeR, M. and Miller, J.D.
Hydrometallurgy, Fundamentals, Technology and Innovations, J.B.Hiskey and G.W.Warren (Eds.), SMME, Warrendale (PA, USA), 1993: 415-436.

(6) Leung, B.K. and Hudson, M.J. Solvent Extr. Ion Exch., 10 (1), 1992: 173-190. 